\title{
A Study on the Hierarchy Analysis for Improving the Utilization of Parks in the Living Area: Case-based on Geumcheon-gu, Seoul, Korea
}

\author{
Xiaolong Zhao ${ }^{1}$, Sunwoo Lee ${ }^{2}$, Heangwoo Lee ${ }^{3}$ \\ ${ }^{1}$ Graduate student, Major of Interior Design, Department of Design, Sangmyung University, Korea, \\ whgyfyd@naver.com \\ ${ }^{2}$ Researcher, Department of Construction Science, College of Architecture, Texas A\&M University, \\ USA,envswlee@gmail.com \\ ${ }^{3}$ Assistant professor, Major of Space Design, College of Design, Sangmyung University, Korea, \\ 2hw@smu.ac.kr
}

Corresponding author: Heangwoo Lee

\begin{abstract}
Recently, the number of city parks that improve citizens' health, recreation, and emotional life is increasing due to efforts to enhance the quality of life. However, the utilization rate is deteriorating because the spatial hierarchy of a park is not sufficiently considered during planning. To address this problem, this study analyzes the spatial hierarchy of city parks in living areas in terms of accessibility and recognizability and then examines the elements that can maximize the use of city parks by observing their actual utilization rate. To achieve the above-stated objective, this study limited the analysis scope to Geumcheon-gu whose number of parks and their areas are well below average, and the space syntax methodology, which can derive spatial hierarchy indicators, was applied to 43 parks in the living areas. In addition, the actual number of people using each park was counted through a field survey and the conclusion was derived through a comprehensive comparative analysis of the spatial hierarchy indicators and actual utilization rate related to the final accessibility and recognizability. In this study, the spatial hierarchy indicators for the accessibility and recognizability of a park were derived based on the traffic lines of living areas in Geumcheon-gu, Seoul. Based on this, the areas with relatively high and low accessibility and recognizability were reviewed. From the comprehensive analysis of derived park indicators and actual visitors' utilization rates, it was found that accessibility and recognizability tended to affect the utilization rates. However, two sports parks in Geumcheon-gu showed a high utilization rate regardless of their accessibility and recognizability. It is postulated that the nature and specific themes of a park are the elements that can improve the utilization rate. To increase the utilization rate of city parks in the future, the residents' demands should be identified when considering accessibility and awareness and it is necessary to reflect these demands.
\end{abstract}

Keywords: Urban Park, Utilization Rate, Improvement, Spatial Hierarchy, Space Syntax

\section{Introduction}

\subsection{Background and Purpose of Study}

As the number of people using parks in a city is recently increasing, the number of city parks is also gradually increasing[1]. City parks are facilities designed to contribute to the protection of natural

Received: July 24, 2020; 1st Review Result: September 12, 2020; 2nd Review Result: October 29, 2020 Accepted: November 30, 2020 
landscapes and the health, recreation, and emotional cultivation of citizens within a city planning area[2]. The demand for such facilities is gradually increasing, but there is a decrease in the number of visitors, lowering its utilization rate because the accessibility and recognizability of a park have not been considered for existing parks[3][4]. In addition, unplanned city parks, which have been increased due to demand, are the main cause of the decline in the utilization rate of city parks[5]. The majority of people who use parks are the elderly, so the accessibility and recognizability of a park should be considered in advance[6]. However, it is true that the various research recently conducted to increase the utilization rate of parks focus only on the unique facility improvement of the park[7-9].

In this respect, the measures to improve the utilization rate of other city parks are very important while ensuring the accessibility and recognizability of a park. Therefore, this study identifies elements that can improve the utilization rate of city parks based on accessibility and recognizability. Furthermore, this study is intended to provide basic data for future city park planning and presents a plan to improve the utilization rate.

\subsection{Procedure and Scope of Study}

This study was conducted in four stages as shown in [Fig. 1] to analyze the accessibility and recognizability of city parks in terms of the living area moving line and spatial hierarchy.

First, the concept and definition of a city park were reviewed theoretically and the role of a park in a city was reviewed. Second, the analysis area and case were selected based on the theoretical consideration and an autonomous district with the least park area and the number of city parks was selected after identifying the parks of each autonomous district in Seoul based on statistical data. The reason why this study selected an autonomous district with the least number of city parks is that the role of a city park is relatively more important in the autonomous district than that of autonomous districts with a larger number of city parks. In addition, this study analyzed the parks in the selected autonomous district, but parks other than those in residential areas were excluded from the scope of this study. Third, after determining the research target, an axis diagram is created using the space syntax program, a quantitative analysis of space is performed, and a result is derived by comparing the connectivity, total integration, and local integration of the entire space and the space adjacent to a park. Fourth, the quantitative analysis results and the actual number of visitors are examined to derive a conclusion through a comprehensive analysis.

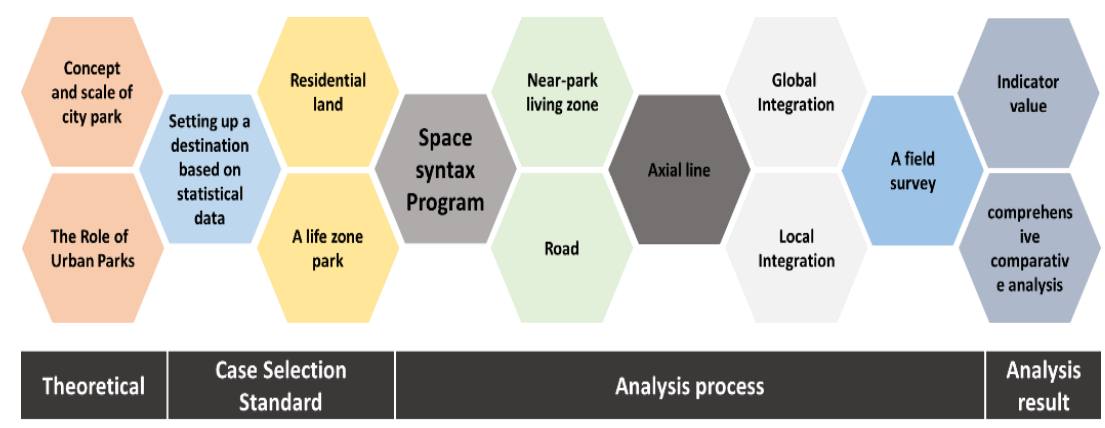

[Fig. 1] Flowchart of Study

\section{Review of City Park Concept, Configuration, and Analysis Method}

\subsection{Definition and Classification of City Park}

The comprehensive concept of a city park is a space or facility that creates a pleasant city environment and contributes to citizens' relaxation and emotional cultivation. A city park was defined in the city 
management plan by the laws and regulations on national land planning and used to contribute to the protection of natural landscapes and improvement of citizens' health, recreation, and emotional life in a city[10]. Facilities close to nature, such as parks located in a city, improve citizens' quality of life in many aspects. In particular, the development of industry and the increase in fossil fuel use are triggering serious problems by causing climate change due to excessive carbon dioxide emissions. Because a park plays a role in responding to these issues, its importance is increasing as time passes. The role of a city park can be classified into spatial, environmental, social, and psychological roles[11][12].

These city parks can be largely categorized into parks that are situated near city living areas and outside the city living area. Usually, they are classified into a living area park and a theme park according to the nature of a park. As shown in [Table 1], a city park should be created according to its characteristics and functions of a park. Its main users according to the characteristics of a city park should be identified and the characteristics of nearby parks should also be considered before construction[13].

[Table 1] Classification of City Parks

\begin{tabular}{|c|c|c|c|c|c|}
\hline \multicolumn{3}{|c|}{ Park } & Concept & Distance & Size \\
\hline \multirow{6}{*}{$\begin{array}{l}\text { Living } \\
\text { area park }\end{array}$} & \multicolumn{2}{|c|}{ Small park } & $\begin{array}{l}\text { Park built to promote relaxation and emotional } \\
\text { cultivation of urban residents using small-scale } \\
\text { land }\end{array}$ & $\begin{array}{l}\text { No } \\
\text { limitation }\end{array}$ & No limitation \\
\hline & \multicolumn{2}{|c|}{ Children's park } & $\begin{array}{l}\text { Park built to contribute to the improvement of } \\
\text { children's health and emotional life }\end{array}$ & $\begin{array}{l}250 \mathrm{~m} \text { or } \\
\text { less }\end{array}$ & $1,500 \mathrm{~m}^{2}$ or more \\
\hline & \multirow{4}{*}{$\begin{array}{l}\text { Neighborhood } \\
\text { Park }\end{array}$} & $\begin{array}{l}\text { Neighborhood } \\
\text { living area }\end{array}$ & Park built for use by people residing nearby & $\begin{array}{l}500 \mathrm{~m} \text { or } \\
\text { less }\end{array}$ & $\begin{array}{l}10,000 \mathrm{~m}^{2} \\
\text { or more }\end{array}$ \\
\hline & & $\begin{array}{l}\text { Walking } \\
\text { distance }\end{array}$ & $\begin{array}{l}\text { Park built for use by people residing within } \\
\text { walking distance }\end{array}$ & $\begin{array}{l}1000 \mathrm{~m} \text { or } \\
\text { less }\end{array}$ & $\begin{array}{l}30,000 \mathrm{~m}^{2} \\
\text { or more }\end{array}$ \\
\hline & & City area & Park used by all residents living in a city & No & $\begin{array}{c}100,000 \mathrm{~m}^{2} \\
\text { or more }\end{array}$ \\
\hline & & Regional area & $\begin{array}{l}\text { Park used by people from multiple cities in a } \\
\text { region }\end{array}$ & limitation & $\begin{array}{l}1,000,000 \mathrm{~m}^{2} \\
\text { or more }\end{array}$ \\
\hline \multirow{6}{*}{$\begin{array}{l}\text { Theme } \\
\text { park }\end{array}$} & \multicolumn{2}{|c|}{ Historical park } & $\begin{array}{l}\text { Park which is built to maintain necessary } \\
\text { hydroponic facilities and convenience facilities } \\
\text { while promoting the conservation and utilization } \\
\text { of cultural assets of high historical value }\end{array}$ & \multirow{6}{*}{$\begin{array}{l}\text { No } \\
\text { limitation }\end{array}$} & \multirow{3}{*}{ No limitation } \\
\hline & \multicolumn{2}{|c|}{ Cultural park } & $\begin{array}{l}\text { Park built to promote leisure, rest, and education } \\
\text { for urban residents by utilizing cultural } \\
\text { characteristics }\end{array}$ & & \\
\hline & \multicolumn{2}{|c|}{ Waterfront park } & $\begin{array}{l}\text { Park built on a waterfront such as a river or a lake } \\
\text { as one of the theme parks among city parks } \\
\text { defined in the City parks and Green Spaces Act }\end{array}$ & & \\
\hline & Cemet & y park & $\begin{array}{l}\text { Parks built by mixing cemeteries and park } \\
\text { facilities under the Burial and Cemetery Act in a } \\
\text { certain area }\end{array}$ & & $\begin{array}{l}100,000 \mathrm{~m}^{2} \text { or } \\
\text { more }\end{array}$ \\
\hline & \multicolumn{2}{|c|}{ Sports park } & $\begin{array}{l}\text { Park built to cultivate a healthy body and mind } \\
\text { through athletic activities such as athletic games } \\
\text { and outdoor activities }\end{array}$ & & \multirow{2}{*}{$\begin{array}{l}10,000 \mathrm{~m}^{2} \text { or } \\
\text { more }\end{array}$} \\
\hline & \multicolumn{2}{|c|}{ City agricultural park } & $\begin{array}{l}\text { Park built as a facility that can harmonize with } \\
\text { urban agriculture }\end{array}$ & & \\
\hline
\end{tabular}




\subsection{Review of Analysis Method}

This study used space syntax to analyze the hierarchy of moving lines in a city park. Space syntax was developed by Bill Hillier and Julienne Hanson of Bartlett Architecture, the University of London to analyze the spatial structure through the connectivity of spaces[14]. Space syntax is a quantitative analysis of the spatial structure and spatial use patterns by reflecting social relations and communication of spatial users and is an appropriate methodology to achieve the purpose of this study. Space syntax is divided into two methods: convex and axial diagram methods, depending on the analysis method and analysis object. This study selected the axial diagram method because the moving line hierarchy within a city should be analyzed. In addition, it is possible to derive connectivity, total integration, and local integration as indicators related to accessibility and recognizability as shown in [Table 2] by using space syntax.

[Table 2] Space Syntax Indicator

\begin{tabular}{cl}
\hline Indicator & \multicolumn{1}{c}{ Indicator Description } \\
\hline Connectivity & A measure of how many spaces are connected to a unit space \\
\hline Integration & $\begin{array}{l}\text { A region with high integration means that movement is relatively easy in the region among the entire } \\
\text { regions to be analyzed }\end{array}$ \\
\hline Local Integration & Calculated by considering only a few space depths from each space, generally three space depths \\
\hline
\end{tabular}

The basic elements of space usage behavior described by the space syntax, which is based on spatial theory, are visibility and accessibility[15]. Visibility, i.e. how much we can see, is the most important variable when using a space, and accessibility is important in the aspect of "how easily we can go from one space to another." In addition, this ease of access is affected by the change of gaze direction rather than the concept of geometric distance, which can be explained by the spatial depth in space $\operatorname{syntax}[16][17]$.

\section{Selection of Analysis Objects and Analysis Results}

\subsection{Analysis Method and Selection of Analysis Objects}

This study was conducted based on the following procedure to analyze the accessibility and recognizability of city parks in the Geumcheon-gu area. First, this study excluded parks located outside the Geumcheon-gu residential areas from the analysis objects and then derived an axis diagram to analyze the moving line hierarchy. The axis diagram of this study refers to urban traffic lines (roads, streets). This study used the map[18] and field surveys provided by Naver Map as of August 20, 2020, to derive the axis diagram. From the derived axis diagram, the values of connectivity, overall integration, and local integration of the Geumcheon-gu residential area were calculated. After that, the average value of the total integration map and the local integration map for the parks in the Geumcheon-gu residential area was derived and the result was compared to the average value of the total integration map and the local integration map for the Geumcheon-gu residential area. However, in this study, an analysis was performed using an axis diagram, and each space was analyzed by considering the axis line adjacent to the entrance of a park as the same line rather than considering them independent moving lines. In addition, this study counted the number of visitors to a park on three different dates, i.e. June 8, 2020, June 15,2020 , and June 22, 2020, to investigate the actual park utilization rate. The survey time was from $6 \mathrm{pm}$ to $10 \mathrm{pm}$ and the number of people entering and leaving the city park was counted for analysis.

This study conducted a spatial hierarchical analysis of a city park, so the selection of analysis objects 
is an important part of this study. Therefore, the scope was primarily limited to Seoul, Korea. Based on 2018 statistical data on the number of parks and area of each autonomous district, the total number of parks in 26 autonomous districts in Seoul was 2,859 as shown in [Table 3] and the total area was recorded as $168,843,300 \mathrm{~m}^{2}[19]$. This is because Seoul has been investing tremendously in city park facilities and is the reason why this study selected Seoul. Based on statistical data on the number of parks and area of each autonomous district in Seoul, this study summarized park quantity and area. Among them, the autonomous districts with a higher number of parks and larger areas include Nowon-gu and Seocho-gu, and the autonomous district with the lowest was Geumcheon-gu. As mentioned earlier, the study was conducted focusing on the analysis of Geumcheon-gu, the autonomous district with the lowest park density and area. For the autonomous districts with a higher number of parks and larger areas, their park density is higher compared to the case with a small number of parks and less area, leading to high accessibility and recognizability of a park. That is why this study selected Geumcheon-gu.

[Table 3] Quantity and Total Area of Parks per Autonomous District of Seoul (as of 2018)

\begin{tabular}{|c|c|c|c|c|c|}
\hline Autonomous district & $\begin{array}{l}\text { Number of } \\
\text { parks }\end{array}$ & Area $\left(1,000 \mathrm{~m}^{2}\right)$ & Autonomous region & $\begin{array}{c}\text { Number of } \\
\text { parks }\end{array}$ & Area $\left(1,000 \mathrm{~m}^{2}\right)$ \\
\hline Jongno-gu & 108 & $11,555.80$ & Mapo-gu & 142 & $4,439.90$ \\
\hline Jung-gu & 70 & $3,132.00$ & Yangcheon-gu & 120 & $2,909.80$ \\
\hline Yongsan-gu & 103 & $1,795.60$ & Gangseo-gu & 167 & $4,329.30$ \\
\hline Seongdong-gu & 85 & $3,102.10$ & Guro-gu & 101 & $3,327.70$ \\
\hline Gwangjin-gu & 59 & $3,363.00$ & Geumcheon-gu & 55 & $2,206.20$ \\
\hline Dongdaemun-gu & 95 & $1,275.80$ & Yeongdeungpo-gu & 125 & $3,091.10$ \\
\hline $\begin{array}{c}\text { Jungnang Autonomous } \\
\text { district }\end{array}$ & 102 & $5,206.30$ & Dongjak-gu & 82 & $4,585.40$ \\
\hline Seongbuk-gu & 127 & $8,342.40$ & Gwanak-gu & 110 & $10,977.10$ \\
\hline Gangbuk-gu & 84 & $14,346.70$ & $\begin{array}{c}\text { Seocho Autonomous } \\
\text { district }\end{array}$ & 165 & $16,036.30$ \\
\hline $\begin{array}{l}\text { Dobong Autonomous } \\
\text { district }\end{array}$ & 79 & $10,075.30$ & Gangnam-gu & 155 & $6,591.70$ \\
\hline Nowon-gu & 181 & $14,337.70$ & Songpa-gu & 168 & $4,642.10$ \\
\hline Eunpyeong-gu & 133 & $13,997.90$ & Gangdong-gu & 124 & $3,370.00$ \\
\hline Seodaemun-gu & 118 & $5,136.10$ & Seoul Grand Park & 1 & $6,670.00$ \\
\hline
\end{tabular}

As a result, this study identified 55 parks located in the Geumcheon-gu area by using the Geumcheongu website. The city parks in Geumcheon-gu are located in Geumha-ro, Gasan-ro, Nambusunhwan-ro, Doksan-ro, Dusan-ro, Beoman-ro, Beotkkot-ro, Siheung-daero, Anyangcheon-ro, and Annae-ro. The majority of these parks are adjacent to Geumha-ro, Doksan-ro, and Siheung-daero. However, this study, as shown in [Table 4], selected a total of 43 parks out of 55 city parks for analysis, excluding 12 city parks not located in residential areas.

[Table 4] Park Area and Quantity per Road Near Geumcheon-gu

\begin{tabular}{cccccc}
\hline No & Park name & Area $(\mathbf{m} 2)$ & No & Park name & Area (m2) \\
\hline 1 & gamlocheonsaengtae & 15,000 & 23 & kkuleogi & 359 \\
\hline 2 & geumcheoncheyug & 18,083 & 24 & bidulgi & 985 \\
\hline
\end{tabular}


A Study on the Hierarchy Analysis for Improving the Utilization of Parks in the Living Area: Case-based on Geumcheon-gu, Seoul, Korea

\begin{tabular}{|c|c|c|c|c|c|}
\hline 3 & sangiseulg & 8,412 & 25 & kkachi & 925 \\
\hline 4 & samseongsan & 10,118 & 26 & jindallae & 992 \\
\hline 5 & doksanjayeon & 7,650 & 27 & dangun & 250 \\
\hline 6 & geumcheonpogpo & 4,835 & 28 & sanjang & 678 \\
\hline 7 & joma & 1,003 & 29 & jangmi & 1,207 \\
\hline 8 & palangsae & 1,502 & 30 & sinheung & 312 \\
\hline 9 & cheoljjug & 1,502 & 31 & hyobong & 503 \\
\hline 10 & puleungol & 977 & 32 & songlog & 947 \\
\hline 11 & mujigae & 972 & 33 & neutinamu & 939 \\
\hline 12 & oggye & 1,059 & 34 & eunhaeng & 865 \\
\hline 13 & mugunghwa & 1,336 & 35 & byeoljang-gil & 971 \\
\hline 14 & jeonghun & 1,094 & 36 & saejaemi & 1,185 \\
\hline 15 & kkumnamu & 576 & 37 & haetae & 963 \\
\hline 16 & dongsan & 1,017 & 38 & neunggolmaeulmadang & 913 \\
\hline 17 & ssamji & 982 & 39 & doksanmaeul & 2,242 \\
\hline 18 & somang & 998 & 40 & damogjeoggwangjang & 1,832 \\
\hline 19 & hansalang & 586 & 41 & geumbich & 5,027 \\
\hline 20 & nammun & 884 & 42 & samseongcheyug & 1,916 \\
\hline 21 & gulyong & 935 & 43 & gong-yong-ui cheongsa & 668 \\
\hline 22 & bansu & 991 & & & \\
\hline
\end{tabular}

\subsection{Spatial Hierarchy Indicators of Park and Site Investigation Results}

This study investigated the spatial structure of a living area in Geumcheon-gu and analyzed the accessibility and recognizability of city parks. The results are as follows.

First, the current Geumcheon-gu residential area consists of a total of 1,913 axis lines and the analysis result of connectivity is shown in [Table 5]. The connectivityis high for Doksan-ro and Nambusunhwanro in Doksan 3-dong, Doksan-ro, Doksan-ro 28-gil and 29-gil in Siheung 4-dong, and 12-gil, 20-gil,and 30-gil in Siheung 3-dong. Therefore, these areas are important in terms of the moving line and are expected to have more moving lines.

Second, the average value of total integration of the Geumcheon-gu living area is 1.064 and the maximum and minimum values are 1.757 and 0.424 for Siheung-daero in Siheung 1-dong and the Tapgol-ro area in Siheung 2-dong, respectively. On the other hand, the average value of total integration of the axis adjacent to the city park is 1.126 , showing a maximum value of 1.723 and the minimum value of 0.486 . This means that there are city parks in Geumcheon-gu with low accessibility although they are located in the living area. In particular, the city parks that have a value below the average of total integration of the entire Geumcheon-gu living area includeGamlocheonsaengtae Park, Geumcheoncheyug Park, Samseongsan Park, Doksanjayeon Park, CheoljjugPark, Kkuleogi Park, Kkachi Park, Jindallae Park, Sanjang Park, Jangmi Park, Sinheung Park, Hyobong Park, Byeoljang-gil Park, Neunggolmadang Park, and Gong-yong-ui Cheongsam Park. Each of these parks is located outside the city. 
[Table 5] Analysis of Connectivity Map of the Living Area and Park in Geumcheon-gu

\begin{tabular}{cc}
\hline $\begin{array}{c}\text { Analysis of the Connectivity of the Living Area of } \\
\text { Geumcheon-gu }\end{array}$ & 27 \\
\hline Max & 1 \\
\hline Min & 3.386 \\
\hline Average & 11.157 \\
\hline $\begin{array}{c}\text { Top 10\% Overall Connectivity Average } \\
\text { Bottom 10\% Overall Connectivity } \\
\text { Average }\end{array}$ & 1 \\
\hline $\begin{array}{c}\text { Analysis of the Connectivity of Park-related Axial Diagrams } \\
\text { in the Living Area of Geumcheon-gu }\end{array}$ & 24 \\
\hline Max & 1 \\
\hline Min & 5.986 \\
\hline Average & 14.923 \\
\hline Top 10\% Overall Connectivity Average & 1.143 \\
\hline Bottom 10\% Overall Connectivity \\
Average
\end{tabular}

[Table 6] Analysis of Integration Map of the Living Area and Park in Geumcheon-gu

\begin{tabular}{|c|c|c|}
\hline \multicolumn{2}{|c|}{$\begin{array}{c}\text { Analysis of the Integration of the Living Area of } \\
\text { Geumcheon-gu }\end{array}$} & \multirow{12}{*}{ <Integration Analysis Result Image> } \\
\hline Max & 1.757 & \\
\hline Min & 0.424 & \\
\hline Average & 1.064 & \\
\hline Top $10 \%$ Overall IntegrationAverage & 1.402 & \\
\hline Bottom $10 \%$ Overall IntegrationAverage & 0.695 & \\
\hline \multicolumn{2}{|c|}{$\begin{array}{c}\text { Analysis of the Integration of Park-related Axial Diagram } \\
\text { in the Living Area of Geumcheon-gu }\end{array}$} & \\
\hline Max & 1.723 & \\
\hline Min & 0.486 & \\
\hline Average & 1.126 & \\
\hline Top $10 \%$ Overall IntegrationAverage & 1.508 & \\
\hline Bottom $10 \%$ Overall IntegrationAverage & 0.768 & \\
\hline
\end{tabular}

Third, as shown in [Table 7], the local integration related to the recognizability of space was derived for the Geumcheon-gu living area. As a result, the average, maximum, and minimum values were 1.902, 3.784 , and 0.333 , respectively. In addition, when deriving the local integration for only the axis adjacent to the city park, the average, maximum, and minimum values are $2.262,3.784$, and 0.333 . From this data, the city parks that may have low recognizability include Gamlocheonsaengtae Park, Geumcheoncheyug Park, Samseongsan Park, Doksanjayeon Park, CheoljjugPark, Oggye Park, Jangmi Park, Hyobong Park, and SamseongcheyugPark. These parks have low accessibility and recognizability from the hierarchical analysis of the moving line system, so their actual utilization rate is expected to be low. In addition, in the case of Gamlocheonsaengtae Park, Geumcheoncheyug Park, Samseongsan Park, Doksanjayeon Park, CheoljjugPark, Jangmi Park, and Hyobong Park, which are located in the direct living area, the average values of total integration and the local integration are all below the average value. Therefore, it is expected that their utilization rate will be low due to low recognizability. 
A Study on the Hierarchy Analysis for Improving the Utilization of Parks in the Living Area: Case-based on Geumcheon-gu, Seoul, Korea

[Table 7] Analysis of Local Integration Map of the Living Area and Park in Geumcheon-gu

\begin{tabular}{|c|c|c|}
\hline \multicolumn{2}{|c|}{$\begin{array}{l}\text { Analysis of the Local Integration of the Living Area of } \\
\text { Geumcheon-gu }\end{array}$} & \\
\hline Max & 3.784 & \\
\hline Min & 0.333 & \\
\hline Average & 1.902 & \\
\hline Top $10 \%$ Overall Local IntegrationAverage & 2.983 & \\
\hline $\begin{array}{l}\text { Bottom } 10 \% \text { Overall Local } \\
\text { IntegrationAverage }\end{array}$ & 0.839 & \\
\hline \multicolumn{2}{|c|}{$\begin{array}{l}\text { Analysis of the Local Integration of Park-related Axial } \\
\text { Diagrams in the Living Area of Geumcheon-gu }\end{array}$} & \\
\hline Max & 3.784 & \\
\hline Min & 0.333 & \\
\hline Average & 2.262 & \\
\hline Top $10 \%$ Overall Local IntegrationAverage & 1.650 & 輩我 \\
\hline $\begin{array}{l}\text { Bottom } 10 \% \text { Overall Local } \\
\text { IntegrationAverage }\end{array}$ & 2.264 & $<$ Local Integration Analysis Result Image $>$ \\
\hline
\end{tabular}

Fourth, as mentioned above, this study counted the number of people visiting the city of Parkson on three different dates, and the results are shown in [Table 8]. The table shows a similar trend to the results obtained earlier, but sports parks show a relatively higher utilization rate. This study makes this assumption because of the nature of the parks. Among the city parks located in the Geumcheon-gu living area, there are two gymnasium parks, i.e. GeumcheoncheyugPark and SamseongcheyugPark, both of which show a high utilization rate.

[Table 8] Identification of Users of Geumcheon-gu Living Area City Parks

\begin{tabular}{cccccc}
\hline Ranking & Park name & $\begin{array}{c}\text { The average } \\
\text { number of visitors }\end{array}$ & Ranking & Park name & $\begin{array}{c}\text { The average } \\
\text { number of visitors }\end{array}$ \\
\hline 1 & mujigae & 577.33 & 22 & haetae & 382.66 \\
\hline 2 & eunhaeng & 576.67 & 23 & hansalang & 380.33 \\
\hline 3 & doksanma-eul & 539.33 & 24 & damogjeoggwangjang & 372.00 \\
\hline 4 & geumbich & 531.67 & 25 & saejaemi & 367.33 \\
\hline 5 & neutinamu & 530.00 & 26 & bidulgi & 359.67 \\
\hline 6 & sangiseulg & 525.67 & 27 & dongsan & 353.00 \\
\hline 7 & jeonghun & 522.33 & 28 & neunggolmaeulmadang & 346.00 \\
\hline 8 & puleungol & 517.33 & 29 & sinheung & 337.67 \\
\hline 9 & Samseongcheyug* & $512.67 *$ & 30 & joma & 328.00 \\
\hline 10 & somang & 504.33 & 31 & byeoljang-gil & 323.33 \\
\hline 11 & ssamji & 493.66 & 32 & kkachi & 310.33 \\
\hline 12 & songlog & 482.67 & 33 & jindallae & 295.33 \\
\hline 13 & Geumcheoncheyug* & $472.00^{*}$ & 34 & samseongsan & 283.33 \\
\hline 14 & mugunghwa & 464.33 & 35 & kkuleogi & 276.67 \\
\hline 15 & gulyong & 449.67 & 36 & gong-yong-ui cheongsa & 269.00 \\
\hline 16 & geumcheonpogpo & 436.33 & 37 & hyobong & 251.33 \\
\hline 17 & nammun & 431.67 & 38 & doksanjayeon & 241.00 \\
\hline
\end{tabular}




\begin{tabular}{lccccc}
\hline 18 & oggye & 419.00 & 39 & jangmi & 227.67 \\
\hline 19 & bansu & 397.33 & 40 & sanjang & 203.67 \\
\hline 20 & dangun & 393.67 & 41 & cheoljjug & 181.67 \\
\hline 21 & kkumnamu & 387.00 & 42 & palangsae & 168.33 \\
\hline & & 43 & gamlocheonsaengtae & 132.67 \\
\hline
\end{tabular}

\subsection{Result Analysis and Discussion}

It is possible to understand the accessibility and recognizability of city parks from the hierarchical analysis of the moving line system and the results prove that the actual number of users is low when the total integration and local integration are low. It was confirmed that the utilization rate of city parks located outside the living area was low due to low accessibility and recognizability. In addition, even for the parks adjacent to the living area, the utilization rate tends to decrease when the recognizability is low, which is an element to be considered when planning a city park in the future. However, based on the number of visitors from site investigations, a special case was found wherein a park with low accessibility and recognizability showed a relatively high utilization rate. In addition, two special cases were sports parks with specific subjects. Therefore, the reason for the high utilization rate was that a specific park theme met nearby residents' demands. In summary, a park with a low utilization rate has low accessibility and recognizability in terms of spatial hierarchy, so the utilization rate is an element that should be considered first when planning a city. For a park that has low accessibility and recognizability, the low utilization rate can be resolved by identifying nearby residents' demands and defining specific themes.

\section{Conclusions}

This study analyzed the accessibility and recognizability of city parks in the Geumcheon-gu living area by using space syntax and verified the results by checking the number of actual users. The conclusions are as follows.

First, this study analyzed the total integration of the Geumcheon-gu living area and city parks. Based on the results, city parks with a relatively low total integration were derived. The city parks derived in this method are considered to have low utilization rates due to low accessibility. Second, this study analyzed local integration by using the axis diagram of the Geumcheon-gu living area and city Parks and derived the city parks with a relatively low value of local integration. As a result, it was possible to derive the city parks with good accessibility but low recognizability although they are adjacent to the living area. Third, based on the results obtained earlier, this study checked the number of actual users of the park and it was possible to derive that the accessibility and recognizability affect the utilization rate. However, there are two sports parks, both showing a high utilization rate. This is because the nature and specific theme of these two parks were by nearby residents' demands. The elements that should be considered first when planning a city park in the future are accessibility and recognizability and it is necessary to identify and reflect nearby residents' demands about a specific theme to improve the utilization rate of an existing park.

Therefore, when planning a park or doing remodeling of a park in the future, it is recommended to understand the residents' demands through a survey and interviews with the nearby residents, reflect the demands in the nature and specific theme of a park, and apply them to the actual park planning and remodeling. This study suggested the elements that can improve a park with a low utilization rate through spatial hierarchy and utilization rate analysis of city parks. This study has significance in that it builds basic data necessary for planning future city parks. However, due to the nature of the analysis 
A Study on the Hierarchy Analysis for Improving the Utilization of Parks in the Living Area: Case-based on Geumcheon-gu, Seoul, Korea

method, there is a limitation in that it cannot reflect all the physical characteristics such as the length of the axis. In the future, a study should be performed by adding more diverse elements through the analysis of cases where the utilization rate was improved through remodeling.

\section{Acknowledgments}

This work was supported by the Ministry of Education of the Republic of Korea and the National Research Foundation of Korea (NRF-2020S1A5A8040240).

\section{References}

[1] B. G. Min, W. S. Jeong, A Study on the Regional Difference of Happiness and Factors Affecting Citizens' Happiness, The Journal of Humanities and Social Sciences 21, (2020), Vol.11, No.2, pp.183-198.

[2] J. Y. Moon, Y. U. Ban, Indicators Development and Rank Decision for Evaluation of Service Supply Level of Urban Living-Zone Parks, Journal of The Urban Design Insitute of Korea, (2018), Vol.19, No.2, pp.39-51, DOI: 10.38195/judik.2018.04.19.2.39

[3] D. I. Kim, H. C. Kim, Spatial Analysis and Strategies with Concept of Catchment Areas to Create City Parks for Everyone Against Lifting of City Parks: A Case Study of 25 Neighborhood Parks in Gwangju, Korea, Journal of the Urban Design Institute of Korea, (2019), Vol.20, No.4, pp.39-56, DOI: 10.38195/judik.2019.08.20.4.39

[4] W. M. Kang, Y. K. Song, H. C. Sung, D. K. Lee, Assessing conservation priorities of unexecuted urban parks in Seoul using ecological network and accessibility analyses, Journal of the Korea Society of Environmental Restoration Technology, (2018), Vol.21, No.2, pp.53-64, DOI: 10.13087/kosert.2018.21.2.53

[5] S. R. Kim, S. G. Park, Analysis of the User Behavior and Recognition in Mudeungsan National Park, Korean Journal of Environment and Ecolog, (2019), Vol.33, No.6, pp.734-747, DOI: 10.13047/KJEE.2019.33.6.734

[6] H. S. Lee, A Study on the Park Service and Seniors' Satisfaction on Park Uses in the Old Town of Seongnam City, Asiapacific Journal of Multimedia Services Convergent with Art, Humanities, and Sociology, (2019), Vol.9, No.10, pp.667676, DOI: 10.35873/ajmahs.2019.9.10.057

[7] I. R. Kim, W. J. Jung, Exploring the Characteristics and Urban Identity of Each Theme Park in Seoul, Journal of the Association of Korean Photo-Geographers, (2020), Vol.30, No.1, pp.1-17, DOI: 10.35149/jakpg.2020.30.1.001

[8] S. S. Kim, A Study on the Writing Strategy Using Example Article of Korean Language Learners, Asia-pacific Journal of Convergent Research Interchange, (2020), Vol.6, No.3, pp.1-9, DOI: 10.21742/apjcri.2020.03.01

[9] J. W. Baik, H. E. Nam, Y. J. Im, J. H. Jang, E. S. Bae, A Study on the Social Welfare Application of the 4th Industrial Revolution:Focus on Social Welfare Major Student, Asia-pacific Journal of Convergent Research Interchange, (2020), Vol.6, No.5 pp.103-110, DOI: 10.21742/apjcri.2020.05.09

[10] D. H. Lee, S. H. Lee, K. Y. Baek, A Study on Children's Park Facility Planning Scheme according to User Behavior and Characteristics, Journal of the Korea Academia-Industrial cooperation Society, (2016), Vol.17, No.12, pp.232-241, DOI: 10.5762/KAIS.2016.17.12.232

[11] http://encykorea.aks.ac.kr/Contents/Index?contents_id=E0015745, Aug 26 (2020)

[12] A. E. Hassanien, J. Mononteliza, Autonomous Driving Path Planning based on Sarsa-Dyna Algorithm, Asia-pacific Journal of Convergent Research Interchange, (2020), Vol.6, No.7, pp.59-70, DOI: 10.47116/apjcri.2020.07.06

[13] http://www.molit.go.kr/USR/law/m_46/dtl.jsp?r_id=6283, Aug 26 (2020)

[14] T. J. Jong, A Study on the Characteristics of Relationship between Pedestrian Environment and Spatial Configuration in Seoul City Center: Focused on the Analysis of Jongro and Cheonggyecheonro Pedestrian Roadside System with Space Syntax, Journal of the Korean Institute of Culture Architecture, (2020), No.70, pp.99-106.

[15] I. S. Kim, Y. O. Kim, A Study on the Tenant Mix Plan Considering the Interrelationship of Spatial Configuration and 
users' Behavior, Journal of the Architectural Institute of Korea, (2019), Vol.35, No.3, pp.3-12.

[16] B. D. Lee, J. S. Lee, J. Y. Kim, A Study on the Trend of Spatial Analysis through Space syntax, Journal of Korea Institute of Spatial Design, (2020), Vol.15, No.3, pp.103-116, DOI: 10.35216/kisd.2020.15.3.103

[17] K. J. Lee, R. Ryu, Y. S. Kim, Analysis on Changes of Accessibility per Period of Outdoor Spaces of Brand-name Apartment Complexes, Asia-pacific Journal of Convergent Research Interchange, (2019), Vol.5, No.2, pp.11-22, DOI: 10.21742/apjcri.2019.06.02

[18] https://map.naver.com, Aug 26 (2020)

[19] https://data.seoul.go.kr, Aug 26 (2020) 